\title{
The Significance of Student Teachers' Involvement in Co-Curricular Activities
}

\author{
Petro Marais \\ Department of Teacher Education, \\ UNISA, Republic of South Africa
}

\begin{abstract}
Around the world teacher training is increasingly offered through open distance learning (ODL). Distance education institutions need to ascertain whether they are producing appropriate made-tomeasure skills that will enable student teachers to educate learners to internationally competitive levels when entering the teaching profession. To reach such levels of competence teacher training should include co-curricular activities, which has also applies to co-curricular activities as these activities are an integral part of teaching. The specific purpose of the research under review has been to determine students' perceptions of their participation in co-curricular activities during teaching practice periods in schools. The research was qualitative and driven by the following research question: What are student teachers' perceptions of the significance of their participation in co-curricular activities for their own professional development? The aims of the research under review were to determine student teachers' perceptions of the following: (1) the nature of co- curricular activities; (2) the value of co-curricular activities for learners; (3) the value of student teachers' participation in co-curricular activities for their own professional development; (4) the effectiveness of teaching practice as presented in an ODL context; and (5) student teachers' recommendations regarding their participation in co-curricular activities by means of ODL. Semi- structured and open-ended questions were used to gather data from the participants. Results confirmed the importance of active participation in co- curricular activities in order to prepare students for their teaching career.
\end{abstract}

Keywords: co-curricular activities; extra-mural activities; non-academic activities; open distance learning $(O D L)$; student teachers; teaching practice

\section{Introduction}

During June 2007 the University of South Africa (UNISA) had a national review regarding a quality assurance audit of the BEd (ECD) programme. During the audit a question was raised about the effectiveness of all aspects of the teaching practice component in one of the ODL-based teacher education programmes, namely the BEd (ECD and Foundation Phase). The study under review focuses on Unisa's four-year bachelor's degree in Education (BEd) with specialisation in Early Childhood Development (ECD and Foundation Phase). The degree consists of 40 modules and comprises the following four major components: three approved school subjects which include the official languages; ten modules in educational themes; fifteen modules in professional studies and additional modules to make up the required number of 40 modules of which four are allocated to teaching practice, namely Teaching Practice 1, 2, 3 and 4. Each of these modules requires 5 weeks of teaching practice, which means that a student has completed 20 weeks of teaching practice in schools by the end of the BEd programme on entry into the teaching profession. The mentoring of student teachers in schools is mainly in the hands of senior teachers referred to as mentor teachers, but lecturers try to visit as many students as possible at least once in the four-year period.

Justification for concern about the significance of cocurricular activities was initially indicated by the findings of research conducted by Kiggundu and Nayimuli which revealed that student teachers' participation in co-curricular activities was excessively restricted despite a request to the School Management Teams (SMTs) to allow student teachers to become involved in such non- academic activities. In fact it was found that student teachers were even excluded from sporting activities [8].

Teaching practice is an integral component of teacher training programmes. Similarly, cocurricular activities albeit not universally known as extra-curricular or non-academic activities (concepts used for this research project) are integral to teaching and learning. By taking up the responsibilities of teaching in the actual teaching and learning environment, student teachers are given the opportunity to experience the real exercise of reflecting rationally and displaying the skills, knowledge and attitudes required in practice by the teaching profession. During teaching practice periods at schools, student teachers must have the opportunity to get involved in all aspects of curricular (academic) as well as co-curricular (non-academic) activities. They need to become acquainted with the nature and challenges of the co- curricular activities of the schools where they do their teaching practice in order to commit to the task of guiding and coaching learners in this regard.

Co-curricular activities fall outside the realm of the normal curriculum of school education. Often a range of activities in the form of classes, clubs and sports activities is available to learners which might 
occur during normal school hours, lunch break or after school [11]. Co-curricular activities which are mostly voluntary are offered throughout the school career from the pre-primary to the secondary level [14].

Where co-curricular activities are compulsory they are viewed as a means to enhance social interaction, leadership, healthy recreation, selfdiscipline and self-confidence. As noted above, in some instances co-curricular activities take place during normal curriculum hours and sometimes not, in which the latter case they require time commitment beyond the regular school day (eg. choir practice). Furthermore, activities offered differ from school to school. Thus, to reiterate in light of the background information given above, the aims of the research under review were to determine student teachers' perceptions of the following:

- The nature of co-curricular activities

- The value of co-curricular activities for learners

- The value of student teachers' participation in cocurricular activities for their own professional development

- The effectiveness of teaching practice as presented in an ODL context

- Student teachers' recommendations

- regarding their participation in co-curricular

- activities by means of ODL

\section{Theoretical framework and literature review}

The integrated theoretical framework applied in this study is based on the constructivist theory of learning postulated by philosophers like Jean Piaget (1896-1980) and Lev Vygotsky (1896-1834).

A constructivist approach emphasises the active role of the student teacher in building understanding and making sense of information as knowledge is constructed by negotiated consensus rather than mere transmission with little or no intellectual participation [6]. This approach is conducive to student-centred teaching and learning (ie. foregrounding the student teacher's own efforts to understand) [15]. Constructivists believe that instead of confronting student teachers with simplified (schematic) problems and basic skills drills they should rather have to deal with complex real-life situations as exemplified in co-curricular activities.

At the same time social constructivist learning does not aim at individual learning. Instead it proceeds from the learning activities experienced in a group will shape individual learners' behavior in the group and therefore the outcomes generated by the collaborative efforts of the group. These group activities should be used to inculcate new strategies and knowledge [15]. Participation in team sports, dancing or clubs is well-suited to the purposes of cocurricular group activities.
Social constructivists view learning as a means to extend individual group abilities in the process of participating with others in activities that are experienced as meaningful. Most social constructivists share two main ideas: (1) that learners actively construct their own knowledge (e.g. student teachers construct their own knowledge and develop their own skills when participating in cocurricular activities) and (2) that social interaction (e.g. co-curricular activities) is an important aid to knowledge construction [1].

The teaching and learning goal envisaged for cocurricular activities is to develop student teachers' abilities to establish and defend their own independently reasoned stance on any matter while respecting the positions of others on similar matters and working together to negotiate or construct meaning by consensus. To accomplish this change, student teachers must talk and listen to each other as well as to mentor teachers, learners, their families and members of the communities concerned as they interpret their co-curricular experiences in social situations. Student teachers use what they know and what the situation provides during social interaction to construct meaning and understanding and to act.

The focus is on how knowledge and skills are imparted by co-curricular activities. Considering that prior knowledge impacts on the learning process, building useful knowledge structures requires effort and purposeful activities. However, this does not mean that mentor teachers have no outcomes planned for student teachers. The mentor teacher has overarching goals that guide planning, but student teachers' ideas and experiences in relation to key topics such as lesson plans, teaching media and assessment criteria are elicited, and learning situations are fashioned that help student teachers to elaborate or restructure their pre- existing knowledge. As student teachers work collaboratively, co-curricular activities naturally lend themselves to using the principles of social constructivism as an aid to imparting knowledge during and after specific activities, especially since the activities concerned are usually undertaken by groups and have welldefined goals.

\section{Teaching practice as a component in teacher training programmes}

Teaching practice is a concept that refers to other terms such as student teaching, field studies, in- field experience, school-based experience or internship [14]. These terms embrace all the learning experiences of student teachers in schools and have three major connotations in common: (1) the practicing of teaching skills and acquisition of the mentor teacher's role; (2) the whole range of student teachers' experiences during teaching practice periods in schools; and (3) the practical aspects of the course as distinct from theoretical studies. Various activities such as the practical use of 
teaching methods, teaching strategies, teaching principles, teaching techniques and practical training are everyday events that student teachers have to deal with.

Besides being an important contribution factor towards the quality of teacher training programmes, teaching practice holds a key position in these programmes as it is a culminating experience to prepare student teachers for the teaching profession. Student teachers feel themselves grow through experiences and they begin to form ties with a culture of instruction [7].

\section{Co-curricular activities in schools}

Examples of co-curricular activities include sports, music lessons, choir practice, debate, religious study (usually sacred scriptures - Biblical, Koranic, Talmudic, etc.), charitable fundraising, theatricals, science clubs, even hobbies such as gardening, crafts, cookery and dancing.

In Singapore's education system separation is made between co-curricular activities and extramural activities. The former, though seen as non- academic, remain a formal part of education with timetabled and compulsory sessions for all learners. Learners can take their pick from a range of co- curricular activities but may not opt out completely. Staff is required to run co-curricular activities as part of their contract and the co-curriculum is generally wellfunded. By contrast, extracurricular activities are less well organised and funded, being entirely voluntary for students and taking place outside the school timetable. School staff may be involved in running extracurricular activities, but there is no obligation on them to do so and they do not normally receive extra pay for it. In many UK and American state schools a distinction is made between co-curricular activities and extracurricular activities [11].

\section{Arguments in favour of co-curricular activities at school}

There are two divergent viewpoints regarding cocurricular activities, some in favour and some opposed [11]. One of the arguments in favour is that these activities prepare learners practically for the future because they get used to working in teams, exercising leadership and taking initiative. The normal curriculum has limitations, with the result that learners who only experienced rigidly academic study may not be able to apply theoretical knowledge in practical situations [11].

Another benefit is that quite a number of activities have a strong physical (as opposed to mental) bias. Learners have to abandon their desks and face new challenges. By giving equal weight to co-curricular and formal academic activities the school system can turn out more versatile and wellbalanced individuals who are more competent all round [11].
Furthermore, it is clearly worthwhile to expose learners to a wide range of experiences that display at least a reasonable resemblance to the reality of conditions in the outside world where they will have to study, live and work once they leave school. It seems justifiable to assume that a judiciously balanced combination of academic and co-curricular learning experiences is likely to enable learners to cope better with life in a society where people have to change career several times in the course of their working lives. Learners must therefore have a working acquaintance with a balanced range of skills [11].

Another argument in favour of co-curricular activities is that every learner has a basic human right to demand and receive a broad education. Learners have different aptitudes and should be given ample opportunities for development before specialising in a specific field of interest. They need skills that will equip them for family and leisure life too. The learner who prefers science should not have to give up music if that is also part of his/her interest range, and a learner who majors in social studies should not be deprived of physical sports activities for that reason.

Moreover, co-curricular activities offered after school hours can be an excellent opportunity to discover new meaning in life rather than waste time lazing around or maybe even making trouble out of boredom.

The success of co-curricular activities often depends on building links between the school and the wider community. This means in practice that local enthusiasts help learners to gain specific skills, and schools send learners out to work on community projects.

Arguments against co-curricular activities in schools Nesan identifies the following arguments against co-curricular activities in schools:

Academic curriculum is much more important and must continue to be given more status in schools than the co-curriculum. Obtaining recognised qualifications is more essential than co-curricular activities. Higher education institutions place a greater importance on the curriculum than on the cocurriculum when selecting students, and so do employers when recruiting workers.

Society does not require masters of many skills, but specialists in selected fields. If a lawyer's legal services are required his ability to tango or play soccer is irrelevant. The main thrust to prepare for gainful employment should therefore go into specialisation for that purpose.

Most specialist professions still provide a range of career opportunities without any need to compromise academic education by overemphasis on nonacademic activities.

Making co-curricular activities compulsory will take the fun out of them and strip them of their benefits. If learners are forced to take part, they will be less enthusiastic and may therefore spoil the activity with their recalcitrance. These arguments are not convincing and are reasonable well answered by 
the arguments in favour of co-curriculum activities.

\section{Teaching practice through open distance learning}

At Unisa - an ODL institution - the lecturers are separated from students in time and space. Contact between students and Unisa's lecturers happens through personal appointments made by students to visit lecturers, or by telephone, email or fax, or by group discussion classes held once or twice a year, or by personal school visits paid by lecturers to students during their teaching practice sessions at schools.

With regard to their teaching practice student teachers have to complete a school placement form indicating the particulars of the school where they intend to do their teaching practice. During each of the four teaching practice periods most of the student teachers receive at least one visit from a lecturer to assess the lesson presentation, then discuss the lesson in light of the assessment and interview the mentor teacher to determine the student's progress. As noted above, the mentor teacher is the classroom teacher who mentors and coaches the student teacher.

During the teaching practice periods student teachers have to apply the theory that, in ODL, is taught by means of purposely designed printed materials, online technology that provides collaboration and support for learning and teaching, SMSs for instant feedback, tips or urgent announcements, satellite broadcasts, and videoconferencing [9]. ODL does not mean student teachers are involved in a passive process of uncritical assimilation of information. On the contrary, they are guided to interact with authors, ideas, opinions, thoughts, impressions and reflections. The object, therefore, in designing tutorial matter for ODL purposes is to achieve twoway communication in which students interact with texts not only to construct their own meaning but also to assess their own learning, thus promoting an in-depth learning approach.

Appropriately designed activities are an obvious way to secure the interaction sought in ODL. Carr, Fung \& Chan [3] note that the most widely used strategy is to integrate questions or activities with the text in order to simulate the learning environment that typifies a traditional (residential/contact based) university/college. By giving critically argued answers to lecturers' questions activities are integrated with the text. By this means the cardinal requirements for successful ODL are satisfied in that "self-instructional materials" are provided. Note that these materials must be accurate, "well-designed, "comprehensive" and at the right academic level [2]. Self-instructional materials should therefore help a student to access sources from which relevant core principles are extracted independently and related to students' particular practical teaching environments.

Furthermore, the questions and activities must be conducive to cultivating independent, critical thinkers who will search deeper and subject ideas to rational scrutiny. Training student teachers' critical thinking is important. They must cultivate critical thinking in their classrooms. They must also be trained in appropriate presentation of content when they themselves teach. Thus, good ODL teacher training material must emphasise the importance of due cognisance of individual differences between learners in "hands-on-teaching situations" and of the fact that such knowledge is gained through keen observation of the learners [13].

Providing excellent tutorial matter in ODL is essential for teacher training by means of ODL. However, student support is an important aid to mastering ODL tutorial matter. An effective ODL environment relies fundamentally on the competencies of the lecturers as well as the infrastructure of the institution in order to provide effective support for students during the learning process [5]. To support students effectively it is most important to identify the roles, outputs and competencies of the teaching and the administrative staff respectively [4]. Research conducted by Mohono-Mahlatsi and Van Tonder (2006) reveal that student teachers who enrolled for ODL training programmes need more support in the form of workshops and personal visits paid by lecturers while engaged in teaching practice periods than their counterparts at contact teaching establishments. Qakisa-Makoe points out that the aim of providing student support is to ensure that students gain "maximum benefit from the whole learning experience" [12].

Awareness of students' characteristics, needs and the difficulties they encounter is essential in ODL. No matter how well-produced the self-instructional materials are, students and especially student teachers must have access to supplementary ODL support systems such as telephone conversations, e- mail and fax correspondence, satellite broadcasting and videoconferencing while doing their teaching practice at schools to help them to overcome the problems they may be facing.

Furthermore, not all the problems of adult students are purely academic in nature, and such personal problems may affect their achievement [3]. It is not realistic to expect all students to function as completely independent learners, be it academically and/or emotionally. They need support. In these cases lecturers must give the student teacher emotional support in the form of sympathetic encouragement. Support through tutorials, workshops and telephone tuition can also enhance successful learning through ODL [3]. Milheim [10] uses the ideas of Cini and Vilic to explain the responsibilities of lecturers regarding student support, not only when they are on teaching practice but throughout the teacher education programme. The responsibilities at issue are also relevant for ODL: (1) coaching students throughout the learning process; (2) focusing on the instructional process in addition to the educational content; (3) encouraging students to be active learners; (4) designing and guiding experiences and activities; and (5) providing explanations, references 
and reinforcement.

\section{Research design}

The researcher employed a qualitative approach couched in a phenomenological research design to obtain an understanding of the views of student teachers regarding co-curricular activities during their teaching practice periods at schools. The reason for the qualitative approach is that variables are usually not manipulated, with the result that understanding of the research phenomenon - in this case fourth-year Unisa student teachers' involvement in co-curricular activities while training - develops naturally.

Data collection was done by means of assignments written by student teachers during their teaching practice period. Several assignments contained hardly any useful data for lack of a substantial factual account. These were excluded from the final sample. Purposeful sampling was used to select 51 information-rich assignments. As stated, the participants were fourth-year students registered for the BEd degree (ECD and Foundation Phase) which is the field in which the researcher teaches. The reason for using fourth-year students was that their earlier three teaching practice modules could be a rich source of data and that their judgement was likely to be more mature than that of younger students. Maximum variation sampling was used. Both genders and a wide age distribution (23 to 61 years) were involved. Moreover, students completed their practice at varied locations, ranging from those that were rich to those that were deficient in human and other resources. Participants also represented a variety of cultural groups.

Table 1. Information about the participants

\begin{tabular}{|c|c|c|c|}
\hline $\begin{array}{l}\text { Gender: } \\
\text { Male } \\
\text { Female }\end{array}$ & $\begin{array}{c}2 \\
49\end{array}$ & $\begin{array}{l}\text { Age: } \\
30 \text { years and younger } \\
31 \text { to } 39 \\
40 \text { years and older }\end{array}$ & $\begin{array}{c}35 \\
15 \\
1\end{array}$ \\
\hline Ethnicity: & & Schools & \\
\hline Coloured & 4 & Urban & 28 \\
\hline Black & 15 & Rural & 23 \\
\hline White & 23 & & \\
\hline Asian & 9 & & \\
\hline
\end{tabular}

Three strategies were used to guard against bias in the findings, namely (1) peer reviewing, (2) participant reviewing and (3) self-monitoring. Peer reviewing was done by three lecturers involved in teaching practice with a view to reaching consensus on the interpretation of results. After interpreting the data, reviewing of the findings was also done by involving 5 participants during an interview for their input and comments. Furthermore, the researcher did her best to avoid bias by resorting to continuous selfmonitoring. Before the research began, the researcher wrote down her own subjective and possibly biased opinions about student teachers' perceptions of co-curricular activities. During the interpretation of data the researcher consciously bracketed these pre-formed opinions. Different tactics were used to eliminate bias. These included maximum variation of participants as well as peer and participant review of the findings.

The data were subjected to content analysis. This was done by organising, analysing and interpreting the data in four stages: (1) identifying keywords such as "understanding”, "nature”, "co-curricular activities", "participation”, "positive aspects" "effectiveness", “ODL”, "learners", “student teachers" and "views"; (2) categorising the responses according to keywords, such as "understanding cocurricular activities", "value of participation", "effectiveness of teaching practice"; consolidation of categories into themes such as "Student teachers' understanding of co-curricular activities" and "Student teachers' perceptions of the value of their participation in co-curricular activities for their own professional development”; and (4) presentation and discussion (interpretation) of themes.

\section{Presentation and discussion of findings}

The findings are organised for discussion according to the following five themes: (1) student teachers' understanding of co-curricular activities; (2) student teachers' perceptions of the value of cocurricular activities for learners; (3) student teachers' perceptions of the value of their participation in cocurricular activities for their own professional development; (4) effectiveness of teaching practice as presented in an ODL context; (5) recommendations made by student teachers regarding their participation in co-curricular activities in an ODL context.

\subsection{Student teachers' understanding of co- curricular activities}

All 51 participants confirmed that co-curricular activities are activities in addition to the academic programme and that these activities were scheduled to take place during breaks, as well as after school hours and on Saturdays. They were also united in their opinion that their participation in the activities concerned had proved distinctly valuable to them. The following are some of their remarks:

- Co-curricular activities are any activity that is part of the curriculum outside the classroom, such as choir, sport tournaments and drama.

- It is extra mural activities that stimulate their (learners') senses according to their level of development.

- It is activities that develop other skills that cannot be developed by means of academic curriculum.

- It is activities that contribute towards the holistic development of a learner.

The research findings on this theme proved that student teachers were familiar with the basic nature of co-curricular activities. They gave examples of 
typical co-curricular activities and expressed the clear opinion that the said activities made an important contribution towards learners' overall development. This is in line with constructivist learning theory, which places a high premium on student-centred teaching and learning and on the student teachers' authentic, self-driven efforts to understand to the exclusion of other premises.

\subsection{Student teachers' perceptions of the value of co-curricular activities for learners}

As noted (see above) another theme that emerged from the data was student teachers' perceptions regarding the beneficial impact of participation in cocurricular activities on learners' educational progress. Determining participants' views on this matter revealed that they knew and understood the learners and could appreciate how they could benefit from the skills imparted to students by their participation in co-curricular activities. These views are reflected in the following comments made by participants:

- It improves their self-esteem and selfconfidence and make them feel worthy

- Co-curricular activities help learners to develop other aspects and skills

- Co-curricular is an outlet for positive energy

- It was an eye-opener to see learners who are not strong in academic subjects flourish on the sport fields.

- These activities promote the well-being of learners and bring out the best in learners

- Co-curricular activities teach learners never to give up

- Learners differ. Not all learners have good academic results and some of these may have excellent talents to achieve outstanding

- results in extra-mural activities such as sport, dancing, or to sing in a choir. This will enhance a positive self-image

- Being involved in sport activities is a solution for behavioural problems

All the participants in the study under review agreed that learner involvement in co-curricular activities provides invaluable learning opportunities. According to the participants, they experienced a marked growth in self-esteem, confidence and achievement. Promoting self- actualisation and selfknowledge is an important part of teaching, and participation in co-curricular activities is a valuable opportunity for learners to acquire these outcomes. Other examples of the value derived by learners from their participation in co-curricular activities are that it teaches perseverance and helps them to find their own strengths. Constructivist learning theory depends critically on the principles of developing learners' sense of responsibility. As student teachers work collaboratively it follows that co-curricular activities are naturally conducive to applying social constructivist principles to transfer knowledge into teaching and learning activities during and after specific activities, especially as the activities are performed by groups to achieve well-defined goals.
Student teachers' perceptions of the value of their participation in co-curricular activities for their professional development

Forty-nine of the 51 participants were positive and excited about participating in co-curricular activities during their teaching practice periods. Their sentiments are exemplified in comments such as:

- It motivated me to be positive about extra- mural activities

- I learnt how to motivate learners and their parents when competition is at stake

- I learnt how to respect learners and their parents

- The school allowed me to be involved in activities of my own choice which I enjoyed

- I learnt to know and understand learners outside of the classroom environment

- Learners see me in a different role and light and they become willing to talk to me about their problems

- I learnt not to become familiar with the learners. They still have to respect you as a teacher

- I learnt to know learners' different levels of physical development when they are involved in sport activities

- Experiences in co-curricular activities canbe reflected on one's CV

- When you apply for a post the school principal can see what skills you as an educator have to offer

- I learnt how to organise events regarding cocurricular activities

However, two participants reported a negative experience as follows:

- I did not have a mentor teacher, so I was left on my own to acquire the necessary sport

- No supervision. A student teacher is lucky if a mentor teacher is available to assist you

- I received negative feedback from the school principal and mentor teachers when the school's team did not win

- Misunderstanding and conflict between mentor teachers were unpleasant. They are supposed to be role models for student teachers

- The mentor teacher embarrassed me in front of the learners by calling me names

It is clear that the vast majority of participants were favourably impressed by the co-curricular activities they had been exposed to during their training years. Some of the positive outcomes are a better understanding of the learners, respecting the learners as well as their parents without being too familiar with them, and realising that they as student teachers have a supportive power during learners' developmental years. Furthermore, the participants improved their knowledge regarding sporting activities and developed organising skills. These outcomes are in accordance with constructivist learning theory which posits that the goal of teaching in cases where it is coordinated with co-curricular activities is to develop student teachers' abilities to establish and defend an independently reasoned stance on any matter while yet respecting the 
positions of others on similar matters and working together to negotiate or construct meaning by consensus. According to constructivist learning theory student teachers use what they know and what the situation provides during social interaction to construct meaning and understanding and to act. Some of the participants indicated that being involved reflected positively on their $\mathrm{CV}$ and that they would benefit from this involvement when they apply for teaching posts in future.

In direct contrast, however, two of the participants did not want to be involved in cocurricular activities during teaching practice periods for fear that it could harm their future teaching careers since their professional development as teachers could not benefit from participation in such activities. This contrasting view is a serious concern because teaching practice periods as discussed offer student teachers an invaluable opportunity to extend their knowledge and skills, as well as the range and depth of the values they espouse, thus lifting their standards of practice in all aspects of teaching.

Being involved in co-curricular activities provides challenges to engage with learners apart from the academic curriculum, to know and understand them outside the formal teaching situation and to focus on their co-curricular abilities and talents. Neglecting or (worse) ignoring the value of co-curricular activities is bound to detract from the quality of training programmes.

The fourth theme that emerged from the data was the effectiveness of teaching practice as presented in an ODL context.

Effectiveness of teaching practice as presented in an ODL context.

Offering teacher training programmes via ODL has advantages as well as challenges. The following is the purport of statements offered by participants in this regard:

- It is effective because one practices cocurricular activities when one is at a school. - . and student teachers have to take responsibility for these activities whether they study at an ODL institution or a residential institution

- It is effective because as a distance learner I do not need to attend classes and have time to teach at a school (internship) longer than the prescribed weeks and therefore students can acquire the necessary skills

- It is effective but enough information should be given to students through tutorial letters and a textbook for teaching practice modules

- ODL provide ample opportunity for a student to be employed full time at a school (internship) in order to be more involved in cocurricular activities

- No evidence of support from lecturers by means of video conferencing or lesson plans on DvDs

Participants indicated that ODL instruction in teaching practice enabled them to take responsibility for their personal and professional growth as individuals. This is in line with constructivist learning theory which proceeds from the premise that learners are active in and assume responsibility for constructing their own knowledge. Furthermore, ODL provides an opportunity to be employed by a school (internship) and student teachers can obtain more exposure to co-curricular activities. This again relates to socio- constructivist theory which defines learning as increasing abilities gained by participating with others in meaningful social interaction. However, it seems as if students need more support by means of video-conferencing and lesson plans recorded on DVDs.

The last theme focused on participants' suggestions regarding measures that could be adopted to support student teachers during their teaching practice periods at schools.

\section{Recommendations from participants (student teachers)}

The following (abridged) recommendations were received from the participants:

- More co-curricular activities should be included in assignments for teaching practice modules

- Participation in co-curricular activities should be made compulsory for student teachers when doing their practicum at schools

- The use of technology in supporting students is important

- We need to be more informed and advised about co-curricular activities by lecturers and mentor teachers

- More modules on sport coaching should be part of the curriculum for teaching practice programmes

These recommendations from participants deserve serious consideration in order to address the needs identified by student teachers regarding their involvement in co-curricular activities.

\section{Conclusions}

As noted at the beginning of this article, the aims of the research under review were to determine student teachers' perceptions of the following: (1) the nature of co-curricular activities; (2) the value of cocurricular activities for learners; (3) the value of student teachers' participation in co-curricular activities for their own professional development; (4) the effectiveness of teaching practice as presented in an ODL context; and (5) recommendations received from student teachers regarding their participation in co-curricular activities by means of ODL.

This article has only been able to touch on some aspects of student teachers' involvement in cocurricular activities during teaching practice periods at schools when studying through ODL. Quality assurance is an uninterrupted process with outcomes that may or may not be measurable but are never final, with the result that constant review in a transparent and professional manner is required for the benefit of the teaching profession.

It seems justifiable to conclude that although both 
positive and negative responses were obtained from the participants with regard to the value and significance for their own professional development of having been involved in co-curricular activities during their teaching practice periods, ODL is a worthwhile option for the purposes of training students to fill the gap left by the shortage of qualified teachers, as well as an effective remedial strategy to enhance the professional competency of under qualified teachers. A comprehensive approach to ODL should be adopted, which should challenge researchers to keep on investigating the efficacy of ODL, not only with regard to teacher education programmes or identified problems, but in a wider ambit, subsuming the roles of lecturers, mentors, tutors, student support services, administrative support, library support, desired programme outcomes and integration of modules without overlapping.

Since a university is expected to encapsulate useful educational ideas and information in teaching programmes that include teaching practice modules, such programmes must be devised and presented to ensure that student teachers acquire the necessary skills to discharge their duties and responsibilities effectively once they enter the teaching profession. Participation in co-curricular activities is an indispensable part of student teachers' preparation for these duties.

\section{References}

[1] Bruning, R.H., Schraw, G.J., Norby, M.M. and Ronning, R.R. 2004. Cognitive psychology and instruction. 4th ed. Columbus, $\mathrm{OH}$ : Merrill.

[2] Cadorath, J., Harris, S. and Encinas, F., 2002. Training for distance teaching through distance learning. Open Learning, 17(2), pp. 139-152.

[3] Carr, R., Fung, Y. and Chan, S.K. 2002. Distance education for teacher education: Hong Kong experience. Journal of In-service Education, 28 (1), pp. 163-178.

[4] Davis, P., Naughton, J and Rothwell, W. 2004. New roles and new competencies for the profession. Are you ready for the next generation? $\mathrm{T}$ and $\mathrm{D}$ Magazine, April, pp. 26-36.

[5] Egan, T. M. and Akdere, M. 2005. Clarifying distance education roles and competencies: Exploring similarities and differences between professional and studentpractitioner perspectives. The American Journal of Distance Education, 19 (2), pp. 78-103.

[6] Gergen, K.J. 1997. Constructing constructivism: Pedagogical potentials. Issues in Education: Contributions from Educational Psychology, 3, pp.195-202.

[7] Gujjar, A.A., 2011. Teaching practice: concept, stages, objectives and proposals. http://www.mazingertz.com/teaching-practice- conceptstages-objectives-and-proposals.html (15 September 2011).
[8] Kiggundu, E. and Nayimuli, S. 2009. Teaching practice: a make or break phase for student teachers. South African Journal of Education, Vol 29(3), pp. 345-358.

[9] Mabunda, P.L. 2010. Information and communication technologies for teaching and learning: Challenges and implications for ODL universities. Progressio, 32(2), pp. 222-244.

[10] Milheim, W., 2001. Faculty and administrative strategies for the effective implementation of distance education. British Journal of Educational Technology, 32(5), pp. 535-542.

[11] Nesan, D. 2009. Co-curricular activities in schools. http://www.idebate.org/debatabase/topic details.php?topicID=839 (10 September 2011).

[12] Qakisa-Makoe, M. 2006. Reaching out: Supporting black learners in distance education.

Progressio: South African Journal for Open and Distance Learning Practice, 27 (1 and 2), pp. 44-61.

[13] Samaras, A. R. 2000. When is a practicum productive? A study of learning to plan.

Action in Teacher Education, 22(2), pp. 100-115.

[14] Taneja, R. P., 2000. Co-curricular activity (Singapore). http://en.wikipedia.org/wiki/Cocurricular_activity_(Singapore) (6 September 2011).

[15] Woolfolk, A. 2010. Educational Psychology. $11^{\text {th }}$ ed. New York: Pearson. 